\title{
AUGUSTUS, WAR AND PEACE
}

By

\section{J. W. RICH}

For the theme of the representation and perception of Roman imperial power to which this volume is devoted no individual could be more central than Augustus and no aspect of his reign of greater importance than his role as both great conqueror and bringer of peace. In this paper I shall discuss not only the presentation and perception of this aspect of the first emperor, but also the policies which lay behind the presentation.

\section{Ideology}

Augustus was proclaimed as a great victor in every contemporary medium. ${ }^{1}$ The preamble of the Res Gestae declares that what follows records the achievements by which "he subjected the world to the empire of the Roman people" (orbem terrarum imperio populi Romani subiecit). Early in the document (3.1-4.2) Augustus tells us that "I often waged civil and external wars by land and sea throughout the whole world" (bella terra et mari civilia externaque toto in orbe saepe gessi), and records among other feats his two ovations, three curule triumphs, 21 imperatorial salutations and 55 supplicationes. A later section (2633) substantiates the preamble's claim of world conquest with a lengthy rehearsal of both military and diplomatic successes.

\footnotetext{
${ }^{1}$ On war and peace in Augustan ideology see especially E. S. Gruen, 'Augustus and the ideology of war and peace', in R. Winkes (ed.), The Age of Augustus (Providence 1985), 51-72; P. Zanker, The Power of Images in the Age of Augustus (Ann Arbor 1988), 79 ff.; 172 ff.; 215 ff.; P. A. Brunt, Roman Imperial Themes (Oxford 1990), 96-109; 433-480; C. Nicolet, Space, Geography and Politics in the Early Roman Empire (Ann Arbor 1991), 15-56; F. V. Hickson, 'Augustus triumphator: manipulation of the triumphal themes in the political program of Augustus', Latomus 50 (1991), 125-138; J. B. Campbell, War and Society in Imperial Rome 31 BC - AD 284 (London 2002), 122132. In general on the Roman cult of victory and other abstractions see J. R. Fears, $A N R W$ II.17.2 (1981), 736-948 (esp. 804 ff., 884 ff. on Augustan developments). E. S. Ramage presents valuable collections of material on Augustan 'propaganda' in Gaul, Spain and Africa at Klio 79 (1997), 117 160; 80 (1998), 434-490; 82 (2000), 171-207. See also G. Cresci Marrone, Ecumene Augustea (Rome 1993); A. Mehl, 'Imperium sine fine dedi - die augusteische Vorstellung von der Grenzlosigkeit des römischen Reiches', in E. Olshausen and H. Sonnabend (eds.), Stuttgarter Kolloquium zur historischen Geographie des Altertums 4, 1990 (Amsterdam 1994), 431-464; K. Balbuza, 'Die Siegesideologie von Octavian Augustus', Eos 86 (1999), 267-299.
} 
The theme was on monumental display all over the city of Rome. In the Senate House Augustus erected an altar and statue of Victory. ${ }^{2}$ Outside, in the Roman Forum, prows from ships captured at Naulochus and Actium were displayed, following Republican precedents, on specially erected columns and on the new Rostra at the front of the temple of Divus Iulius. ${ }^{3}$ Alongside that temple stood Augustus' triple arch, erected, as I have recently argued, to celebrate the Actium victory and later adapted to commemorate the Parthian settlement as well. ${ }^{4}$ A short distance away was Augustus' own new Forum, built from his spoils, whose decorations, as Velleius tells us, included tituli of the peoples he had conquered. ${ }^{5}$ Elsewhere in the city were other commemorations of Augustus' conquests, for example the obscure Porticus ad Nationes, perhaps the model for the Sebasteion at Aphrodisias. ${ }^{6}$ Two Egyptian obelisks were set up in 10/9 BC, with inscriptions recording their dedication to the Sun, "Egypt having been brought into the power of the Roman people" (Aegupto in potestatem populi Romani redacta); one was erected on the spina of the Circus Maximus, and the other as the gnomon of a sundial, laid out in the northern Campus Martius between Augustus' Mausoleum and the Altar of Pax Augusta. ${ }^{7}$ Also in the Campus Martius stood the Porticus Vipsania, completed from Agrippa's designs by his sister. As Pliny tells us (Naturalis historia 3.17), Agrippa planned there "to set the world before the city for inspection" (orbem terrarum urbi spectondum propositurus). Brodersen has recently reminded us just how fragile is the basis for the usual view that the Porticus contained a map of the world. ${ }^{8}$ However, even if

\footnotetext{
${ }^{2}$ Cassius Dio 51.22.1-2; V. Ehrenberg \& A. H. M. Jones, Documents illustrating the Reigns of Augustus and Tiberius (Oxford 1967, 2nd ed.) [hereafter, EJ, 51; T. Hölscher, Victoria Romana (Mainz 1967), 6-17; LTUR 5.150 (E. Tortorici).

${ }^{3}$ Columns: Appian, Bella civilia 5.130; Servius, ad. Georg. 3.29; LTUR 1.308 (D. Palombi). Rostra: Cassius Dio 51.19.2; LTUR 3.117 (P. Gros).

${ }^{4}$ J. W. Rich, 'Augustus's Parthian honours, the temple of Mars Ultor and the arch in the Forum Romanum', Papers of the British School at Rome 66 (1998), 71-128.

${ }^{5}$ Res Gestae 21.1; Velleius Paterculus 2.39.2, with Rich 1998, op.cit. (n.4), 123-124.

${ }^{6}$ Servius, ad Aen. 8.721; R. R. R. Smith, 'Simulacra gentium: the Ethne from the Sebasteion at Aphrodisias', Journal of Roman Studies 78 (1988), 50-77.

${ }^{7}$ EJ 14; Pliny, Naturalis Historia 36.70-73. Recent studies have shown that the pavement was a meridian-instrument, not a true sundial, and have refuted E. Buchner's hypothesis that its equinoctial line intersected with the Ara Pacis: M. Schutz, 'Zur Sonnenuhr auf dem Marsfeld', Gymnasium 97 (1990), 432-457; T. Barton, 'Augustus and Capricorn: astrological polyvalency and imperial rhetoric', Journal of Roman Studies 84 (1994), 33-51, at pp. 44-46.

${ }^{8} \mathrm{~K}$. Brodersen, Terra Cognita: Studien zur römischen Raumerfassung (Hildesheim, Zurich \& New York 1995), 268-285. For the usual view of the monument as a map, see especially Nicolet 1991,
} 
he is right that it merely housed an inscription, the monument must still have been intended as an emblem of Augustan world rule.

Elsewhere in the empire Augustus the victor was celebrated by numerous arches, and by other monuments such as the memorial for the Actium victory erected on the site of his camp and just outside Nicopolis, the new 'Victory City', or the trophies erected at St-Bertrand-de-Comminges and La Turbie in honour of the successes in Spain, Gaul and the Alps. ${ }^{9}$ The goddess Victory, often shown surmounting a globe (as probably in the Senate House statue), was one of the commonest types on the Augustan coinage, and this and related themes often appear in private art, for example the Boscoreale cups, where Venus is shown placing Victory on a globe held by Augustus. ${ }^{10}$

When civil wars ended, Octavian/Augustus was (like Caesar earlier) honoured as bringer of peace. ${ }^{11}$ Thus the column erected after his victory over Sextus Pompeius in $36 \mathrm{BC}$ bore the inscription: "Peace, long disturbed, he reestablished on land and sea". ${ }^{12}$ More in the same vein followed the victories over Antony and Cleopatra. In $29 \mathrm{BC}$, the augurium Salutis was held and the shrine of Janus was closed, both deemed to require universal peace. ${ }^{13}$ The closure of Janus was an antiquarian revival of a rite whose attribution to Numa had probably been invented at the time of the only previous historical celebration in $235 \mathrm{BC}$, and of which Augustus' contemporaries will have been reminded by Varro's

op.cit. (n.1), 95-122; J. Engels, Augusteische Oikumenegeographie und Universalhistorie im Werk Strabons von Amaseia (Stuttgart 1999), 359-377.

${ }^{9}$ For overviews see W. Mierse, 'Augustan building programs in the western provinces', in K. A. Raaflaub and M. Toher (eds.), Between Republic and Empire: Interpretations of Augustus and his Principate (Berkeley, Los Angeles \& Oxford 1990), 308-333; Ramage, opp. citt. (n.1); D. Kienast, Augustus: Prinzeps und Monarch (Darmstadt 1999, 3rd ed.), 417-449. The Actium memorial: W. M. Murray and P. M. Petsas, Octavian's Campsite Memorial for the Actium War (Philadelphia 1989). Trophies: G. Charles-Picard, Les trophées romains (Paris 1957), 253-311; Ramage 1997, op.cit. (n.1), 125-126.

${ }^{10}$ Hölscher, op.cit. (n.1), 6-47; A. L. Kuttner, Dynasty and Empire in the Age of Augustus: the Case of the Boscoreale Cups (Berkeley, Los Angeles \& Oxford 1995), 13-34.

${ }^{11}$ On the Roman conception of peace and on honours for Caesar and Augustus as bringers of peace see especially S. Weinstock, 'Pax and the "Ara Pacis"', Journal of Roman Studies 50 (1960), 44-58, at pp. 44-50. Weinstock's suggestion that Caesar planned to institute a cult of Pax is fanciful, and his rejection of the identification of the surviving monument with the Ara Pacis Augustae is perverse, but the article remains an invaluable collection of evidence.

${ }^{12}$ Appian, Bella civilia 5.130 .

${ }^{13}$ Res Gestae 13; EJ p. 45; Livy 1.19.3; Suetonius, Augustus 22, 31.4; Cassius Dio 51.20.4. 
researches. ${ }^{14}$ The occurrence of the same phrase in several sources' reference to this closing of Janus suggests that the senate's decree expressly linked it with the establishment of peace 'on land and sea', adapting a formula first used of Hellenistic rulers. ${ }^{15}$ About the same time the goddess Pax figured on the coinage of both Italian and Eastern mints. ${ }^{16}$

Later in the reign Augustus continued to be celebrated as bringer of peace. The closure of Janus was decreed twice more during his reign, in 25 $\mathrm{BC}$ after his successes in Spain and at an uncertain later date. ${ }^{17}$ An altar of Augustan Peace (Pax Augusta) was decreed on Augustus' return to Rome in $13 \mathrm{BC}$ and dedicated in $9 \mathrm{BC}$, surviving to become for us the most famous of all Augustan monuments. ${ }^{18}$ The cult is attested elsewhere too: an altar to Pax Augusta from Narbo appears from its decoration to be of Augustan date, while Strabo records Paxaugusta as the name of a colony. ${ }^{19}$ Other provincial celebrations of Augustus the peace-maker include a well-known decree of the Koinon in Asia in $9 \mathrm{BC}$, in which he is praised as "the saviour who has brought war to an end", and the dedication of a gold statue to Augustus in the Forum Augustum at Rome by the province of Baetica "because by his beneficence and perpetual care the province has been pacified". ${ }^{20}$

\footnotetext{
${ }^{14}$ Weinstock 1960, op.cit. (n.11), 48. See also R. Turcan, 'Janus à l'époque imperiale', ANRW II.17.1 (1981), 374-402; G. Forsythe, The Historian L. Calpurnius Piso and the Roman Annalistic Tradition (Lanham 1994), 185-193; LTUR 3.92-93 (E. Tortorici).

${ }^{15}$ A. Momigliano, 'Terra marique', Journal of Roman Studies 32 (1942), 53-64. Cicero had already spoken of Pompey as having established universal peace by land and sea: In Catilinam 2.11 omnia sunt externa unius virtute terra marique pacata; cf. De Imperio Cn. Pompeii 56; Pro Flacco 29; Pro Balbo 16; ILS 8776. The inscription on the Actium memorial at Nicopolis proclaims its dedication pace parta terra [marique]: EJ 12; Murray and Petsas 1989, op.cit. (n.9), 76.

${ }^{16}$ RIC Augustus 252-253; 476. The goddess Peace also appears on two civic coinages of the Augustan period: RPC I.1529 (Pella); 2062 (Nicomedia).

${ }^{17}$ Res Gestae 13; Suetonius, Augustus 22; Cassius Dio 53.26.5; 54.36.2; Orosius 6.21.11; 22.1; R. Syme, Roman Papers III (Oxford 1984), 1179-1197; VI (Oxford 1991), 441-450; and see below.

${ }^{18}$ Res Gestae 12.2; EJ pp. 46; 49; Cassius Dio 54.25.3. K. Galinsky, Augustan Culture (Princeton 1996), 141-155, is a good recent overview, for further bibliography see Kienast, op.cit. (n.9), 239240; LTUR 4.70-74 (M. Torelli). Note also the statue of Pax dedicated by Augustus, along with statues of Salus Publica and Concordia, in 10 BC (Cassius Dio 54.35.2)

${ }^{19}$ See Weinstock 1960, op.cit. (n.11), 48; 54. The altar: ILS 3789. The colony: Strabo 3.2.15 (151C). Strabo mentions the colony in his account of Spain, but describes it as in Gaul. Not otherwise attested, it is perhaps to be identified with Pax Iulia (the modern Beja) in Lusitania. The foundation (or refoundation) will doubtless have taken place in 15-14 BC, when Augustus founded a number of colonies in Gaul and Spain (Res Gestae 16.1; Cassius Dio 54.23.7).

${ }^{20} \mathrm{EJ} 42$ (Baetican statue); 98 line 36 (Asian decree).
} 
Significant though this evidence is, it is clear that Peace was accorded much less prominence in the Augustan media than Victory. ${ }^{21}$ There was in any case no contradiction between the commemoration of Augustus as victor and as peacemaker, since in the Roman conception pacification was achieved through victories. Thus Cicero could speak of Macedonia as having been "pacified by many victories and triumph" (multis victoriis ... triumphisque pacata), and claims for triumphs were commonly linked with the pacification of the commander's province. ${ }^{22}$ Caesar in the De bello gallico repeatedly marks his progress by speaking of part or all of Gaul as pacata by his victories. ${ }^{23}$ Augustus himself in the Res Gestae asserts that tradition required the closure of Janus when over the whole empire "peace had been won by victories" (esset parta victoriis $p a x$ ), and in his later review of his successes in war he boasts of having pacified the sea, the Gallic and Spanish provinces, Germany and the Alps. ${ }^{24}$ Similarly, Velleius, in a brief survey of Augustus' achievements, speaks of his having "pacified the world by victories", and goes on to sketch the pacification of the West, and in particular of Dalmatia, the Alps and Spain.25

Nevertheless, there was great ambivalence both in Augustus' external achievements and in the ways in which they were perceived and presented. Augustus and those commanding under his auspices conquered more territory than anyone before or after in Roman history. The civil wars had closed with the annexation of Egypt. The achievements of Augustus' sole rule included the conquest of north-west Spain and the Alps and of a vast tract in the Balkans extending as far as the Danube. He also claimed the conquest of Germany as far as the Elbe, only to see it fall out of Roman control in his last

\footnotetext{
${ }^{21}$ Rightly remarked by Gruen, op.cit. (n.1); Ramage 1997, op.cit. (n.1), 136 ff.; Ramage 1998, op.cit. (n.1), $462 \mathrm{ff}$.

${ }^{22}$ Macedonia: Cicero, De provinciis consularibus 4 . Triumphs: e.g. Livy 39.29.5; 41.12.10; 41.17.3; Suetonius, Iulius 18.1.

${ }^{23}$ Caesar, De bello gallico $2.35 .1 ; 3.7 .1 ; 28.1 ; 4.37 .1 ; 6.5 .1 ; 7.65 .4$.

${ }^{24}$ Res Gestae 13; 25.1 (mare pacavi a praedonibus); 26.2-3 (Gallias et Hispanias provincias, item Germaniam qua includit Oceanus a Gadibus ad ostium Albis fluminis pacavi. Alpes a regione ea, quae proxima est Hadriano mari, ad Tuscum pacificavi).

${ }^{25}$ Velleius Paterculus 2.89 .6 (bella sub imperatore gesta pacatusque victoriis terrarum orbis); 90.1 (Delmatia ... ad certam confessionem pacata est imperii. Alpes feris incultisque nationibus celebres perdomitae. Hispaniae nunc ipsius praesentia, nunc Agrippae ... multo varioque Marte pacatae); 91.1 (dum pacatur occidens). Note also 2.126.3, where Velleius includes among the blessings of Tiberius' reign the universal diffusion of pax augusta (the only occurrence of the phrase in a literary source).
} 
years as a result of Varus' disaster. However, his reign also marked the end of steady Roman expansion. The empire at his death could be spoken of as "enclosed by the Ocean and by long rivers", ${ }^{26}$ and Claudius and Trajan were the only subsequent emperors to make major additions to the empire. In avoiding expansion, his successors were following the advice which Augustus had left them. Among the documents which Augustus left and which were read out in the senate after his death was a summary of the resources of the empire, and to this summary, written in his own hand, he had appended the advice that the empire should be kept within its bounds. ${ }^{27}$ Thus, by the end of his life, Augustus had concluded that the expansion to which he had made so notable a contribution should go no farther.

Later writers sometimes downplay Augustus' conquests, apparently influenced by their knowledge of the sequel and in some cases by their own prejudices against expansion. Thus Suetonius, writing under Hadrian, who had abjured expansion, passes over the conquests very briefly, stressing instead Augustus' restraint in his dealings with foreign peoples, and he later remarks on Augustus' insistence that battles or wars should not be begun unless the prospective gain exceeded the loss risked. ${ }^{28}$ Florus, who criticizes the inertia of Augustus' successors, makes much more of Augustus' wars, but still ends his work with an effusion on Augustus' establishment of universal peace. ${ }^{29}$ Cassius

\footnotetext{
${ }^{26}$ Tacitus, Annales 1.9.5: mari Oceano aut amnibus longinquis saeptum imperium.

${ }^{27}$ Tacitus, Annales 1.11.4: quae cuncta (sc. the summary of imperial resources) sua manu perscripserat Augustus addideratque consilium coercendi intra terminos imperii. The failure of Suetonius, Augustus 101.4, to mention this advice is not an argument against its authenticity. According to Cassius Dio 56.33.3-6 the warning against expansion formed part of a separate document devoted to advice; this elaboration is certainly fictional and may be Dio's own work. It is uncertain whether the summary of resources with its appended advice against expansion was read along with the other documents at the first senate meeting, before Augustus' funeral (so Dio), or separately at the second session on 17 September at which Augustus' deification was decreed (so Tacitus; EJ p. 52 for the date). Tacitus' language is naturally interpreted as meaning that Augustus had added the advice in writing, not orally, contra J. Ober, 'Tiberius and the political testament of Augustus', Historia 31 (1982), 306-328. It is in any case unlikely that Tiberius would have presumed to invent the advice, as Ober maintains.

${ }^{28}$ Suetonius, Augustus 21; 25.4. At 21.2 Suetonius cites the oaths which Augustus administered to some barbarian chieftains and his practice on hostages as evidence of how much "he lacked the desire to increase empire or military glory by whatever means" (tantum afuit a cupiditate quoquo modo imperium vel bellicam gloriam augendi). The passage does not allege that he lacked such desire altogether, as supposed by, e.g., Gruen 1985, op.cit. (n.1), 67 n. 92, and Brunt 1990, op.cit. (n.1), 465, disregarding quoquo modo.

${ }^{29}$ Florus 2.34. Successors' inertia: Florus 1. praef. 8.
} 
Dio, who makes no secret of his opposition to expansion in his own day, regularly depreciates Augustus' wars and perversely claims that he both preached and practised the policy of not extending the empire throughout his reign. This distorted view led him to interpret as a general statement against imperial expansion a letter sent by Augustus to the senate in $20 \mathrm{BC}$, which must in fact have had a more limited application and probably referred primarily to the decision to leave Armenia and other territories as client kingdoms rather than annexing them as provinces. ${ }^{30}$ The emperor Julian, in his satire The Caesars, makes Augustus boast that "I did not give way to boundless ambition and aim at enlarging the empire at all costs, but assigned for it two boundaries defined as it were by nature herself, the Danube and the Euphrates". ${ }^{31}$

It was not only later writers who misinterpreted Augustus' intentions. Contemporary perplexities can be traced in the evidence of the poets. Parthia was the principal business which Augustus' predecessors had left unfinished. Crassus' invasion of Parthia had ended in his defeat and death at Carrhae in $53 \mathrm{BC}$, and since then the Parthians had been the Romans' greatest enemy. Caesar's planned invasion had been pre-empted by his death, and further humiliations had followed: the Parthians had invaded Syria in $40 \mathrm{BC}$, defeating and killing the legate L. Decidius Saxa; Antony had invaded Parthia in $36 \mathrm{BC}$, but his rearguard under Oppius Statianus had been annihilated, and winter had forced him to withdraw under Parthian harassment. The Parthians still held captives and standards from Crassus', Decidius' and Antony's armies. Other peoples too remained in defiance, including the Britons: revolt in Gaul had prevented Caesar from carrying out the conquest of Britain which he had essayed through his invasions in 55-54 BC, and no subsequent commander had taken up the challenge.

In the first years of Augustus' sole rule, Virgil, Horace and Propertius make frequent prophecies of grand conquests for Augustus which would extend Roman rule to the ends of the earth and over Parthia in particular. Several of Horace's poems also look forward to the subjugation of Britain. Horace's Regulus Ode provides a concise formulation:

\footnotetext{
${ }^{30}$ Cassius Dio 54.9.1. Other references to the supposed policy of non-expansion: 53.10.4; 56.33.5-6; 41.7. See Brunt 1990, op.cit. (n.1), 106; 462; 466-468; J. W. Rich, Cassius Dio, The Augustan Settlement Roman History 53-55.9) (Warminster 1990), 17; 183.

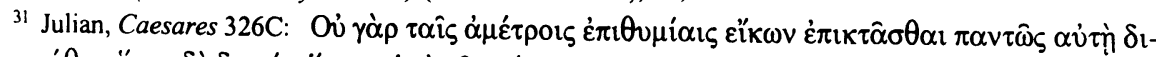

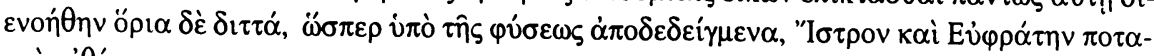
$\mu$ oùs $\dot{\varepsilon} \theta \dot{\varepsilon} \mu \eta$ v.
} 
caelo tonantem credidimus Iovem

regnare: praesens divus habebitur

Augustus adiectis Britannis

imperio gravibusque Persis.

In heaven his thunder taught us Jupiter

Is king. Augustus will be held a god

Amongst us, when to the empire

He adds the Britons and grim Persians [sc. Parthians] ${ }^{32}$

The poets may be taken as reflecting public expectations and as writing what they thought might please the emperor himself. The Roman public, then, expected Augustus to embark on great wars of foreign conquest like those of Pompey and Caesar, and above all to subjugate the Parthians by force of arms. ${ }^{33}$

The expected attacks on Parthia and Britain never took place. Whether Augustus ever contemplated an invasion of Britain remains uncertain. Dio's reports that he was planning an invasion in 34, 27 and $25 \mathrm{BC}$ may perhaps derive from contemporary rumours, but it is unlikely that he was seriously considering such an enterprise in those years. ${ }^{34}$ With Parthia Augustus consistently pursued a diplomatic solution. This bore fruit in 20 $\mathrm{BC}$, when he induced the Parthian king Phraates to surrender the Roman captives and standards in return for Roman friendship, and he continued to rely on diplomatic methods in his dealings with Parthia throughout the rest of his reign.

Even after the settlement of $20 \mathrm{BC}$ expectations of Parthian conquest were not wholly abandoned. Thus Propertius speaks of Parthian trophies as

\footnotetext{
${ }^{32}$ Horatius, Carmina 3.5.1-4. For expected Parthian and British conquest see also Horatius, Carmina 1.35.29-32; cf. Epodi 7.7-10, Carmina 1.21.15. For other prophecies of Parthian and wider conquest see Vergilius, Georgica 3.32-33; 4.61; Aeneis 7.603-606; Horatius, Sermones 2.1.14-15; Carmina 1.2.51-52; 1.12.53-57; 1.29.1-5; 2.9.18-24; 3.3.43-48; Propertius 2.10.13-18; 3.4.1-6.

${ }^{33}$ For full discussion of the poets' treatment of external policies and expectations see H. D. Meyer, Die Aussenpolitik des Augustus und die augusteische Dichtung (Cologne 1961), with the criticisms of Brunt 1990, op.cit. (n.1), 96-109, and W. Schmitthenner, Gnomon 37 (1965), 152-162. There is no need to suppose that Horace was offering a personal critique of Augustus' inactivity, as suggested by R. Seager, 'Neu sinas Medos equitare inultos: Horace, the Parthians and Augustan foreign policy', Athenaeum 58 (1980), 103-118. On the poets' relationship with the Augustan regime see above all P. White, Promised Verse: Poets in the Society of Augustan Rome (Cambridge, Mass. 1993).

${ }^{34}$ Cassius Dio 49.38.2; 53.22.5; 53.25.2; Rich 1990, op.cit. (n. 30), 156-157.
} 
postponed for Augustus' adopted sons Gaius and Lucius to win, and, on the eve of Gaius' departure for the East in $1 \mathrm{BC}$, Ovid prophesied the triumph he would celebrate over Parthia. In the event, Gaius restored good relations, as Augustus had no doubt always intended, meeting the new king Phraataces in person in $\mathrm{AD} 2 .{ }^{35}$

Horace, however, takes a different line in poems written after the settlement of $20 \mathrm{BC}$ and one which is closely in accord with the picture Augustus himself was to present in the Res Gestae. World rule and universal peace is no longer presented as in the future, to be accomplished by Augustus' expected wars of conquest, but as having been already achieved by his military and diplomatic successes. The Parthian settlement was at the heart of this claim: Augustus maintained, with little or no justification, that he had 'compelled' the Parthians to return the Romans' standards and spoils and to seek their friendship as 'suppliants', and they are represented on the coinage and elsewhere as surrendering the standards on bended knee. ${ }^{36}$ Further support was supplied by the fortuitous arrival, about the same time, of embassies from the Scythians and Indians. ${ }^{37}$ Hence Horace's proud boast in the Carmen Saeculare:

iam mari terraque manus potentis

Medus Albanasque timet securis, iam Scythae responsa petunt superbi nuper et Indi.

Now the Mede [sc. the Parthian] fears the forces strong by land And sea and the Alban axes; now

The Scythians, formerly proud, and the Indians

\footnotetext{
35 Propertius 4.6.80-82; Ovidius, Ars Amatoria 1.177-228; Remedia Amoris 155-158. Gaius' meeting: Velleius Paterculus 2.101; Cassius Dio 55.10a.4.

${ }^{36}$ Res Gestae 29.2: Parthos trium exercitum Romanorum spolia et signa reddere mihi supplicesque amicitiam populi Romani petere coegi. Kneeling Parthians: Horatius, Epistulae 1.12.28; RIC Augustus 287-289, 304-305, 314-315; R. M. Schneider, Bunte Barbaren (Worms 1986), 18-97. For other sources on the settlement of 20 BC see Rich 1990, op.cit. (n.30), 180-181. For its commemoration in art see especially Zanker 1988, op.cit. (n.1), 186-192.

${ }^{37}$ Listed along with other embassies from far-flung peoples at Res Gestae 31. Other sources include Strabo 15.1.4 (686C); 15.1 .73 (719-720C); Suetonius, Augustus 21.3; Florus 2.34.62; Orosius 6.21.19. Augustus received an Indian embassy while he was in Spain and a second in Syria in 20 BC.
} 


\section{Seek responses.}

In the following lines Horace celebrates the return of Peace and Plenty along with the old Roman virtues. ${ }^{38}$ These diplomatic successes along with the recent victories in Spain and the Alps are adduced as attesting universal acceptance of Roman authority in several other of Horace's poems of the period, and sometimes the Parthians' submission is explicitly linked with the closure of Janus. ${ }^{39}$ The celebration of Augustan peace and world rule is later taken up by Ovid, notably in the closing lines of the Metamorphoses and in his treatments of Janus and the Ara Pacis in the Fasti. ${ }^{40}$

The claim that Augustus had achieved world rule appears not only in the poets, in the Res Gestae and in art, but also in a writer as sober as Strabo. The conception of the Roman empire as effectively coterminous with the inhabited world runs through Strabo's universal geography. ${ }^{41} \mathrm{He}$ recognises, of course, that some of the regions of which he treats, such as Britain, Parthia and India, still lay outside the empire, but he contrives to suggest that what was outside the empire was either not worth conquering or had already effectively submitted or both. Thus he argues that the annexation of Britain would not be cost-effective and that the Britons' embassies to Augustus show the island to be already virtually subject to Rome. The Dacians too he represents as having come near to submission to the Romans, claiming that it was only their hopes of the Romans' German enemies that prevented their complete subjection. As for the Parthians, while he elsewhere speaks of them as rivals of the Romans, he optimistically concludes his sketch of the stages by which the Romans had acquired universal hegemony by adducing the Parthians' return of their spoils, entrusting of royal princes to Augustus as hostages and reception of one of these princes as king as evidence that they

\footnotetext{
${ }^{38}$ Horatius, Carmen Saeculare 53-60.

${ }^{39}$ Horatius, Epistulae 1.12.25-29; 1.18.54-57; 2.1.253-256; Carmina 4.5.25-28; 4.14.41-52; 4.15.4-9; 4.15.21-24. The same associations reappear later at Florus 2.34. Similarly, the cuirass of the contemporary Prima Porta statue of Augustus depicts the Parthian surrender of the standards with flanking figures representing other submissive peoples.

${ }^{40}$ Ovidius, Metamorphoses 15.822-839; 860; Fasti 1.277-288; 1.711-718.

${ }^{41}$ See K. Clarke, Between Geography and History: Hellenistic Constructions of the Roman World (Oxford 1999), 307-328; Engels 1999, op.cit. (n.8), 303-313; 337-358; D. Dueck, Strabo of Amasia: A Greek Man of Letters in Augustan Rome (London \& New York 2000), 96-129.
} 
had gone far towards accepting Roman supremacy and were on the point of submitting themselves entirely to the Romans. ${ }^{42}$

Such claims were, of course, grossly exaggerated. The despatch of embassies was in itself not a mark of submission, whether from remote peoples such as the Indians and Scythians or from the much closer Britons. Augustus boasted in the Res Gestae that his army had "obliged the Dacians to submit to the commands of the Roman people", but in reality all that had been achieved against them had been the repulse of Dacian raiders and on one occasion a punitive expedition across the Danube. ${ }^{43}$ Augustus had indeed erased the disgrace of past Roman defeats at Parthian hands, but at the cost of accepting peaceful co-existence with this powerful neighbour. It is no accident that we are given no details of the manner in which the Roman standards and captives were returned: we may be sure that in reality no Parthian bended the knee. Phraates' despatch of his sons to Rome served his own domestic convenience, and Vonones, sent back by Augustus to take the throne at Parthian request in $\mathrm{AD} 6$, was ousted six years later. ${ }^{44}$

There were, however, long-established features of the Roman outlook which made it easier for Augustus and his loyal supporters to claim that he had brought the world under Roman rule. The Romans, like the Greeks, had a firmly Mediterranean-centred view of the world. This had made it possible for them to be spoken of as world-rulers by Polybius and other Greeks since the second century BC, and Romans themselves had made such claims from at least the early first century. The vast conquests of Pompey and Caesar had further strengthened the case, and both had been acclaimed as extending Roman rule to the ends of the world. ${ }^{45}$ Such views were facilitated not only

\footnotetext{
${ }^{42}$ Britain: Strabo 4.5.3 (200-201C), well discussed by D. C. Braund, Ruling Roman Britain (London 1996), 80-89. Dacia: 7.3.13 (305C). Parthians as rivals: 11.9 .2 (515C). Effective universal rule and Parthians near submission: $6.4 .2(288 \mathrm{C})$; cf. 17.3 .24 (839C). There is no need to explain the apparent inconsistencies in Strabo's statements about the Parthians in terms of different stages of composition: so rightly Dueck 2000, op.cit. (n.41), 113-115; contra R. Syme, Anatolica (Oxford 1995), 365-366; Brunt 1990, op.cit. (n.1), 436-437. Similar interpretations of the Parthian royal hostages: Res Gestae 32.2; 33; Suetonius, Augustus 21.3.

${ }^{43}$ Res Gestae 30.2: trans Danuvium ductus exercitus meus Dacorum gentes imperia populi Romani perferre coegit. For the expedition across the Danube see EJ 43a; the commander was probably M. Vinicius, as argued by R. Syme, Danubian Studies (Bucharest 1971), 26-39.

${ }^{44}$ Strabo 16.1.28 (748-749C); Josephus, Antiquitates iudaicae 18.41-9; Tacitus, Annales 2.1-2.

${ }^{45}$ On pre-Augustan claims to Roman world-rule see especially Nicolet 1991, op.cit. (n.1), 29-56, citing the evidence.
} 
by the limitations of contemporary geographical knowledge, but also by the ambiguities of the Roman conception of empire, which embraced not only those directly ruled in provinces but also the Romans' other friends and allies - kings, peoples and cities. Not since the early second century had they been obliged to treat with another nation on truly equal terms, and the line between friends and subjects had long been conveniently blurred. It was thus easy enough to hope that the friendship concluded with the king of Parthia might evolve into a client relationship like that with an Amyntas or a Herod and to speak as though it had already done so. ${ }^{46}$

Nevertheless, while the claim that Augustus had subjected the world to the empire of the Roman people stood in a well-established Roman tradition, Augustus was making a dramatic breach with tradition in basing this claim as much on diplomatic successes as on military victories. The Parthian settlement was the first time that the Romans had resolved a major dispute with a foreign power by diplomacy rather than by force of arms, and, as we have seen, this outcome ran counter to the public's expectations. For reasons of policy Augustus decided to make a peaceful settlement, despite the pressures of tradition and popular anticipation. To compensate, he was obliged to represent the settlement as a bloodless victory, and the fervour with which it was celebrated by the poets, in the coinage and in art reflects the regime's eagerness to portray it as a great Roman success.

As I have argued elsewhere, the honours which Augustus accepted for his Parthian success were, even more than on other occasions, the outcome of a delicate negotiation between those conferring the honours (in this case, the senate) and their recipient. By a becoming parade of modesty Augustus avoided accepting honours which would have contrasted too sharply with the bloodless character of his Parthian success, but he ensured all the same that it received exceptional commemoration. The princeps insisted on maintaining his by now established practice of entering the city quietly rather than in ovation or a curule triumph. He declined a new arch, but agreed that additions commemorating the settlement should be made to the Actium arch, in the form of figures of Parthians offering up standards. He declined a temple of Mars Ultor on the Capitol to house

\footnotetext{
${ }^{46}$ Cf. Brunt 1990, op.cit. (n.1), 433-438. On the Roman conception and organization of their empire see A. W. Lintott, Imperium Romanum: Politics and Administration (London \& New York 1993), $16-42$.
} 
the standards, but went on to build a much larger temple to that god and partly for that purpose in his own new Forum. ${ }^{47}$

By contrast, the commemoration of the great Augustan wars of conquest is comparatively low-key. To some extent, this may reflect the accidents of survival. Thus Kuttner has argued plausibly that the Boscoreale cups celebrate Tiberius' triumph of $7 \mathrm{BC}$ and derive from a lost monument. ${ }^{48}$ However, it is striking how few contemporary coin types relate to the wars in central Europe: the conquest of the Alps in $15 \mathrm{BC}$ is commemorated only in a small group of Lugdunum issues showing one or two soldiers (perhaps to be identified as Tiberius and Drusus) offering a branch to Augustus seated on a tribunal, while no coin issues directly relate to the great wars in Germany and the Balkans in the following years. ${ }^{49}$ Much larger issues produced at Lugdunum over the same period show Apollo and Diana in an explicit and strangely belated celebration of the victories at Actium and Naulochus. ${ }^{50}$

The relatively low prominence accorded to the great victories in central Europe is no doubt to a large extent due to the fact that they were won not by Augustus himself nor by the (still infant) Gaius and Lucius whom he intended to succeed him, but by his stepsons Tiberius and Drusus. They were allowed to accumulate military honours, but only by a carefully staged process, culminating in Tiberius' triumph in $7 \mathrm{BC} .^{51}$ By then, commanders outside the imperial family had ceased to hold triumphs. Augustus himself continued to accept military honours, taking supplicationes and imperatorial salutations and dedicating the laurels from his fasces on his return to Rome

\footnotetext{
${ }^{47}$ Rich 1998, op.cit. (n.4), with earlier bibliography. On the origins of the temple of Mars Ultor and the Forum Augustum, I am in substantial agreement with M. Spannagel, Exemplaria Principis: Untersuchungen zu Entstehung und Ausstattung des Augustusforums (Heidelberg 1999), 15-255, on which see my review at Bryn Mawr Classical Review 2002.03.21.

${ }^{48}$ Kuttner 1995, op.cit. (n.10).

${ }^{49}$ Soldier(s) offering branch: RIC Augustus 162-165. The twelve year old C. Caesar's service with the German legions in 8 BC (Cassius Dio 55.6.4) is commemorated on RIC Augustus 198-199. The scene shown on RIC Augustus 200-201 is plausibly interpreted by Kuttner 1995, op.cit. (n.10), 94123 , as representing the offer of child hostages by Gallic chieftains. The barbarian offering a vexillum on RIC Augustus 416 is probably a Gaul rather than a German: Augustus is not known to have recovered standards from Germans, but claims to have done so from Gauls at Res Gestae 29.1.

${ }^{50}$ RIC Augustus 170-173; 179-183; 190-197; 204. For a different view of the commemoration of the successes in Germany see R. Wolters, 'Germanien im Jahre 8 v. Chr.', in W. Schluter \& R. Wiegels (eds), Rom, Germanien und die Ausgrabungen von Kalkriese (Osnabrück 1999), 591-636, at pp. 606615.

${ }^{51}$ See further J. W. Rich, 'Drusus and the spolia opima', Classical Quarterly 49 (1999), 544-555.
} 
after a salutation. However, after the Spanish war of 26-25 BC, he no longer campaigned in person, and he had in any case resolved to hold no more triumphs, enhancing the glory of his triple triumph of $29 \mathrm{BC}$ by preserving its uniqueness. ${ }^{52}$

\section{Policies}

What then were the policies which lay behind this varied record of conquest and diplomacy with its grandiose presentation and shifting public perceptions? Widely divergent answers to this question are offered by modern scholarship.

It was until comparatively recently generally assumed that Augustus' external policies were defensive and aimed at the preservation of peace throughout the empire and the establishment of secure frontiers. On this view, Augustus undertook the great advance in central Europe simply because he conceived it as necessary to secure the empire from external threats. ${ }^{53}$

The grand scale of Augustus' expansion to the Danube and the Elbe is an obvious difficulty for this thesis, and some have accordingly sought instead to explain this advance primarily in terms of a search for a shorter frontier. The most fully developed exposition of this view is that of Syme. For Syme Augustus was concerned not so much with frontiers as with communications, and it was to Illyricum that he attached most importance. The civil wars had revealed the possibility of a split between the eastern and western halves of the empire, and to avert this Augustus advanced to the Danube to secure the land route from Italy to the Balkans by the Save valley. With the advance to the Danube decided on, it seemed prudent to advance also to the Elbe, to provide a shorter line of communications for the more efficient protection of the empire against possible threats from beyond the frontier. ${ }^{54}$

Syme's imaginative conception has been widely followed, but is surely fanciful. It was only in the later empire that Illyricum and its land route attained the strategic importance which so engaged Syme. It is unlikely that

\footnotetext{
${ }^{52}$ See further Hickson 1991, op.cit. (n.1).

${ }^{53}$ W. A. Oldfather \& H. V. Cantor, The Defeat of Varus and the German Frontier Policy of Augustus (Urbana 1916), 54-70, conveniently surveys older views. For a clear statement of the traditional view see Meyer 1961, op.cit. (n.33), 1-13. See also H. E. Stier, 'Augustusfriede und römische Klassik', ANRW II.2 (1975), $3 \mathrm{ff}$.

${ }^{54}$ R. Syme, in CAH X (Cambridge 1934), 340-381, esp. 351-354. For Syme's later restatements of his view see Danubian Papers (above, n.43), 13-25; History in Ovid (Oxford 1978), 51-52; Roman Papers VI (Oxford 1991), 129-141, 372-397.
} 
Augustus would have thought that there was much risk of the empire splitting on territorial lines, let alone that he would have conceived of an advance in Illyricum as a security against such a danger. In view of the Romans' ignorance about the geography of central Europe before his invasions, Augustus could hardly have discerned the supposed advantages of the Elbe as a frontier. Recent work has in any case effectively challenged the notion that the Roman imperial frontiers were ever conceived as linear and 'scientific', and it is altogether improbable that Augustus would have undertaken the huge advance into central Europe in the pursuit of such a chimera. ${ }^{55}$

Other scholars have challenged the defensive interpretation of Augustus' aims and have argued instead that he sought unlimited expansion and aspired to the conquest of the whole known world. This thesis has been most cogently stated by Brunt. ${ }^{56}$ Brunt's arguments have persuaded so many scholars that his view has now become orthodoxy. ${ }^{57}$ This doctrine accords better than the traditional defensive interpretation both with the huge scale of Augustan expansion and with the emphasis on Augustus' victories and on his extension of empire in the Res Gestae and other media. Augustus' advice to his successors against expansion is not a difficulty, since on any view it represents a departure from the policy which he had himself earlier pursued. However, the supposition that Augustus aimed to conquer the whole world

\footnotetext{
${ }^{55}$ Roman frontiers not linear or 'scientific': see especially B. Isaac, The Limits of Empire: The Roman Army in the East (Oxford 1992, rev. ed.), esp. 372-418; C. R. Whittaker, Frontiers of the Roman Empire: A Social and Economic Study (Baltimore \& London, 1994), 1-97; S. Mattern, Rome and the Enemy: Imperial Strategy in the Principate (Berkeley, Los Angeles \& London 1999), esp. 109-122. For critiques of Syme's theory see Brunt 1990, op.cit. (n.1), 102; 455-456; N. J. E. Austin and B. Rankov, Exploratio: Military and Political Intelligence in the Roman World from the Second Punic War to the Battle of Adrianople (London \& New York 1995), 125-127.

${ }^{56}$ P. A. Brunt, review of Meyer 1961, op.cit. (n.33), Journal of Roman Studies 53 (1963), 170-176, reprinted in his Roman Imperial Themes (above, n.1), 96-109. Brunt amplifies and in some respects modifies his view at Roman Imperial Themes 433-480.

${ }^{57}$ Brunt is followed by e.g. C. M. Wells, The German Policy of Augustus (Oxford 1972), 1-13; A. R. Birley, 'Roman frontiers and Roman frontier policy: some reflections on Roman imperialism', Transactions of the Architectural and Archaeological Society of Durham and Northumberland 3 (1974), 13-25; Ober 1982, op.cit. (n.27); P. Garnsey and R. Saller, The Roman Empire: Economy, Society and Culture (London, 1987), 7; Nicolet, op.cit. (n.1), 29-30; T. J. Cornell, in J. W. Rich and D. G. J. Shipley, War and Society in the Roman World (London \& New York 1993), 139-42; Mattern 1999, op.cit. (n.55), 89-91, 107; Kienast 1999, op.cit. (n.9), 332 ff. Austin \& Rankov 1995, op.cit. (n.55), 127-128, doubt whether Augustus aimed at world conquest, but suppose that he sought expansion of the empire without a clear idea of how far he would advance.
} 
by force of arms is uncorroborated speculation and is supported neither by the contemporary testimony nor by Augustus' actions. It is true that the poets in the 20's BC envisaged military conquests extending to the ends of the earth, but, as we have seen, their expectations of British and Parthian wars came to nothing, and their later claim that Augustus had already achieved world rule through his diplomatic and military successes gives no support to Brunt's thesis. Although the Romans greatly underestimated the extent of the regions beyond the boundaries of their empire, they recognized that the unconquered territory was very large ${ }^{58}$ Augustus' forces launched no more than a punitive expedition across the lower Danube against the Dacians, and he decided not to extend hostilities beyond the Elbe, instructing his generals (probably from $8 \mathrm{BC}$ ) not to pursue emigrating tribes beyond it. ${ }^{59} \mathrm{~L}$. Domitius Ahenobarbus' crossing of the Elbe in $1 \mathrm{AD}$ was not a breach of that instruction, since he contented himself with establishing friendship with the tribes on the farther bank and establishing an altar to Augustus. ${ }^{60}$ Augustus could, of course, have envisaged that further advances beyond the Elbe and lower Danube might be made at some later date, but we have no warrant for supposing that he entertained such notions.

The greatest weakness of Brunt's thesis is its failure to account for the avoidance of war with Parthia. Brunt claimed that the conquest of Parthia had merely been postponed until after that of central Europe. ${ }^{61}$ That is most implausible. If Augustus had intended to conquer Parthia as public opinion had expected, he would surely have accorded it the highest priority. That war with Parthia should be avoided if at all possible was evidently an axiom of his policy from which he never wavered.

Both Syme's and Brunt's hypotheses share the assumption that Augustus set his sights firmly on a single, overriding goal and pursued it consistently at any rate down to Varus' disaster, but it is surely more likely that his external policies evolved over the course of his long reign. There is thus some attraction in the view of Gruen that, behind the grandiose rhetoric, Augustus was a simple pragmatist in these matters, responding to events as

\footnotetext{
${ }^{58}$ On the Romans' conception of the extent of the regions outside the empire see Brunt 1990, op.cit. (n.1), 107-108; 449-450; 455-456; Nicolet 1991, op.cit. (n.1), 57-122; Mattern 1999, op.cit. (n.55), 24-80.

${ }^{59}$ Strabo $7.1 .4(291 \mathrm{C})$.

${ }^{60}$ Cassius Dio 55.10a.2; Tacitus, Annales 4.44.2.

${ }^{61}$ Brunt 1990, op.cit. (n.1), 105-107; 456; 460-464.
} 
they arose ${ }^{62}$ However, this presents, in my view, too passive a picture to give an adequate explanation of the many external initiatives of at least the first half of Augustus' reign and in particular of the great advance into central Europe.

An adequate account of Augustus' external policies should allow for their evolution over time. It should set them against the background of the traditional expectations and assumptions of Roman dealings with external peoples. And, I would like to suggest, it should relate them more closely to internal political imperatives than has generally been customary. ${ }^{63}$

One such imperative we have already noticed, namely the popular expectation that he would embark on great wars of conquest. If he was not to disappoint, Augustus had either to satisfy these expectations or offer an acceptable substitute. Another imperative was Augustus' own dynastic aspirations. If he was to succeed in founding a dynasty, he needed to provide both his intended successors and other members of his family with the opportunity to acquire glory and charisma. It was clearly with this in mind that Augustus withdrew himself from frontline command at a relatively early age and from 15 $\mathrm{BC}$ entrusted the important campaigns in central Europe to Tiberius and Drusus. Augustus must have planned that Gaius and Lucius should have at least commensurate opportunities, but fate prevented him from achieving whatever designs he had for them.

What has not, to my mind, attracted sufficient notice is how closely Augustus' external policies were integrated with his solutions to the problems of the army and of his own position in the state.

His victory over Antony left Octavian/Augustus in control of an army of some sixty legions, in which many veterans were clamouring for their rewards. The huge ensuing demobilization reduced the army to a force of 27 or 28 legions, with their accompanying auxiliary troops, stationed in some seven provinces. In a radical departure from earlier practice, Augustus

\footnotetext{
${ }^{62}$ E. S. Gruen, 'The imperial policy of Augustus', in K. A. Raaflaub and M. Toher (eds.), Between Republic and Empire: Interpretations of Augustus and his Principate (Berkeley, Los Angeles \& London 1990), 395-416; id., 'The expansion of the empire under Augustus', in CAH 10 (1996²), 147197; cf. id., 'Augustus and the ideology of war and peace' (above, n.1).

${ }^{63}$ The importance of political and dynastic motives for Augustus' wars is rightly stressed by Campbell 2002, op.cit. (n.1), 4-9; B. M. Levick, 'Augustan imperialism and the year 19 BC', in A. F. Basson \& W. J. Dominik (eds.), Literature, Art and History: Studies on Classical Antiquity in Honour of W. J. Henderson (Frankfurt 2003), 305-22.
} 
thereafter avoided raising new legions for specific occasions, opting instead to meet Rome's military needs from the permanent establishment, with units being redeployed as required, and as a result he was able to develop a planned solution to the great problem of the rewards for discharged veterans. ${ }^{64}$

Octavian laid the basis for his own position in the state in the great settlement of 28 and $27 \mathrm{BC}$, by which he established his monarchy in a republican guise, and for which he was rewarded, among other honours, with the name Augustus. New light has been thrown on the settlement by a recently discovered aureus, dated by its obverse legend to Octavian's sixth consulship (28 BC). The reverse, which shows Octavian seated on a curule chair and holding out a scroll and bears the legend LEGES ET IVRA P R RESTITVIT ("he had restored their laws and rights to the Roman people"), accords with his statement in the Res Gestae that the settlement took place over his sixth and seventh consulships, and shows that Dio was guilty of radical distortion in compressing the whole settlement into an offer to surrender power made in a single senate meeting in $27 \mathrm{BC}$. The first stages of the settlement, carried out in $28 \mathrm{BC}$, probably included not just the annulment of Octavian's illegal and unjust acts, but also other measures such as the reform of the treasury and the restoration of free elections. For the final stage, at the senate meeting of 13 January $27 \mathrm{BC}$, were left the most crucial matters: the armies and the provinces. ${ }^{65}$

The appointment of provincial governors presented Octavian/Augustus with a particularly delicate problem. If his claim to have transferred the republic to the control of the senate and people was to have any substance, he could not continue to appoint the governors as before, but he could not surrender the choice of military commanders without jeopardizing the control of the armies on which his power ultimately depended. The solution which he devised was one of characteristic brilliance. $\mathrm{He}$ announced the transfer of the provinces in the senate, but made sure that

\footnotetext{
${ }^{64}$ For convenient overviews of Augustus' military reforms see K. Raaflaub, 'The political significance of Augustus' military reforms', in W. S. Hanson \& L. J. F. Keppie (eds.), Roman Frontier Studies 1979 (Oxford 1980), 1005-1026; L. Keppie, The Making of the Roman Army (London 1998, rev. ed.), 134-171; Kienast 1999, op.cit. (n.9), 320-332.

${ }^{65} \mathrm{~J}$. W. Rich \& J. H. C. Williams, 'Leges et iura p. R. restituit: a new aureus of Octavian and the settlement of 28-27 BC', Numismatic Chronicle 159 (1999), 169-213. In general on Augustus' constitutional powers see now J.-L. Ferrary, 'À propos des pouvoirs d'Auguste', Cahiers Glotz 12 (2001), 101-154.
} 
there would be protests, and then, after a show of reluctance, consented to resume the bulk of the military provinces, leaving the remainder to the Roman people. This compromise permitted the resumption of sortition for the proconsuls of the public provinces, while Augustus continued to appoint the governors of his own provinces, who as his legati were no longer eligible for imperatorial salutations or triumphs. ${ }^{66}$

A justification was, however, needed for the retention of most of the military provinces, and Augustus supplied this by declaring that he was keeping them for a limited period only in order to carry out a programme of empire-wide pacification. As Dio puts it, "he retained the stronger provinces on the grounds that they were insecure and dangerous and either had enemies on their borders or were capable of launching a serious rebellion on their own", and he accepted the provinces only for ten years, promising to restore them to order within that time and to return them sooner if he completed the task more quickly. ${ }^{67}$ The justification conformed to and built on traditional assumptions. As we have seen, commanders had commonly claimed to have pacified their provinces. ${ }^{68}$ Pompey had been credited with worldwide pacification through his campaigns against the pirates and in Asia, not only in Cicero's speeches but also in the text of a law. ${ }^{69}$ Augustus had been acclaimed as the bringer of peace throughout the empire by land and sea through his ending of the civil wars. He now undertook to make this claim good by accepting the command of the insecure provinces with the declared objective of pacifying both them and their neighbours.

Augustus doubtless always intended that at the expiry of the ten years it should be found that further time was needed to complete the pacification,

\footnotetext{
${ }^{66}$ In general on the provincial settlement see Rich 1990, op.cit. (n.30), 141 ff. F. Millar, “"Senatorial provinces": an institutionalized ghost', Ancient World 20 (1989), 93-97 (reprinted in his Rome, The Greek World and the East I (Chapel Hill \& London 2002), 314-320), rightly reminds us that those provinces not retained by Augustus were transferred to the Roman people, not the senate, and so should be spoken of as public, not senatorial provinces.

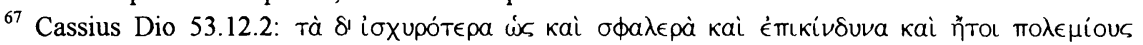

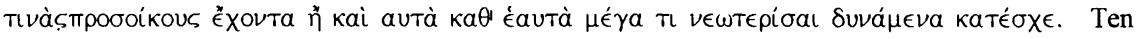
years: Cassius Dio 53.13.1.

${ }^{68}$ Above, nn. 22-23.

${ }^{69}$ Cicero: De provinciis consularibus 31 , nulla gens est quae non aut ita sublata sit ut vix exstet aut ita domita ut quiescat aut ita pacata ut victoria nostra imperioque laetetur, other passages cited at n. 15 above. Law: Lex Gabinia Calpurnia de Insula Delo, lines 19-20, imperio am[pli]ficato [p]ace per orbe [m terrarum confecta] (M.H. Crawford, Roman Statutes I (London 1996), 346).
} 
and so indeed it proved. Dio tells us that, with fresh shows of reluctance, he accepted a five-year renewal in $18 \mathrm{BC}$, soon afterwards extended to ten, and further renewals, each time for ten years, in $8 \mathrm{BC}, \mathrm{AD} 3$ and $\mathrm{AD} 13 .{ }^{70}$ From Tiberius' accession in $\mathrm{AD} 14$ the division of the provinces became permanent. From now on it was accepted that the emperor should hold the provinces which required a military garrison, and this conception is reflected in the way in which the contemporary Strabo and later Suetonius report Augustus' division of the provinces. ${ }^{71}$

The familiarity of the division of the provinces as a permanent feature of the imperial system has perhaps led us to overlook the fact that at the outset the promise of pacification cannot have been just an idle pretext. If Augustus had done nothing to implement his promise, he would have exposed the settlement as an empty charade. Thus Augustus was committed, particularly in the first part of his reign, to carrying out the programme of pacification. This will in any case have chimed well with his other interests: it required him to be absent from Rome for extended periods, a prudent device to allow the new system to bed down, and it enabled him to meet the challenge of satisfying public expectations of conquest.

So, I would argue, Augustus' external policies should be interpreted in terms of the fulfilment of the undertaking of pacification given in January $27 \mathrm{BC}$, and, particularly in the first part of the reign, the rhythm of those policies can be seen to be related to the renewals of the provincial division. In conclusion, I shall briefly sketch the outlines of such an interpretation. ${ }^{72}$

\footnotetext{
${ }^{70}$ Cassius Dio 53.16.2; 54.12.4-5; 55.6.1; $12.3 ; 56.28 .1 ; 39.6$. Dio describes these extensions as renewals of the 'leadership' (prostasia) or 'supremacy' (hegemonia). This may merely reflect his interpretation of the significance of the division of the provinces, but it may alternatively indicate that Augustus accepted an informal oversight of the res publica at the same time: see Rich 1990, op.cit. (n.30), 139-140; Rich \& Williams 1999, op.cit. (n.65), 211-212; contra, Ferrary 2001, op.cit. (n.65), 113-115.

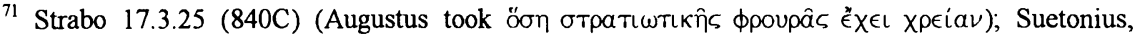
Augustus 47 (provincias validiores et quas annuis magistratuum imperiis regi nec facile nec tutum erat ipse suscepit).

${ }^{72}$ For recent overviews of Augustus' conduct of external affairs, citing sources and further bibliography, see Gruen, opp.citt. (n.62); Kienast 1999, op.cit. (n.9), 332-377 (acutely noting the link with the division of the provinces at pp. 333, 352, 525). See also J. Bleicken, Augustus: eine Biographie (Berlin 2000), 565-618; W. Eck, The Age of Augustus (Oxford 2003), 93-104.
} 


\section{Implementation}

The principal provinces which fell to Augustus in the division of $27 \mathrm{BC}$ were Spain, Gaul, Syria and Egypt. This made good sense in terms of the programme of pacification: there had been recent disturbances in Gaul and Spain, Syria bordered Parthia, and Egypt was a major new acquisition, not yet fully brought under control. These provinces held the majority of the legions, but between five and eight legions overall remained in three public provinces, namely Africa, Illyricum and Macedonia. Africa was of relatively little military importance, and Augustus could not plausibly have claimed in $27 \mathrm{BC}$ that the Balkan provinces needed pacification. He himself claimed to have pacified Illyricum by his campaigns of 35-33 BC, celebrated on the first day of the triple triumph of $29 \mathrm{BC}$. As for Macedonia, the proconsul M. Licinius Crassus had recently achieved remarkable successes beyond the frontiers of the province, killing an enemy commander with his own hands and advancing to the Danube. ${ }^{73}$

Augustus began his programme of pacification in Spain, heading there in his first extended absence from Rome, from 27 to 24 BC. In Spain, he embarked on the conquest of the north-west, the only part of the Iberian peninsula to have remained outside Roman control. That this campaign was the first stage of the promised pacification was symbolically marked by the reopening of the temple of Janus and its second closure when he finished campaigning in $25 \mathrm{BC}$. Augustus' own campaigns did not end all resistance, but his legates, followed by Agrippa, completed its elimination before the tenyear period was up. ${ }^{74}$

Meanwhile in Egypt, the first three of Augustus' prefects were all militarily active. C. Cornelius Gallus subdued Upper Egypt and both he and the third prefect $P$. Petronius engaged with the Ethiopians. These activities could be represented as part of the programme of pacifying the troubled provinces and the regions beyond their frontiers. The expedition of the second prefect, Aelius Gallus, into Arabia was an unprovoked quest for glory and profit, although the proximity of southern Arabia to the Horn of Africa and so to Egypt's southern neighbours may have provided some shred of

\footnotetext{
${ }^{73}$ For Crassus' exploits and their significance see Cassius Dio 51.23-27; J. W. Rich, 'Augustus and the spolia opima', Chiron 26 (1996), 85-127.

${ }^{74}$ For the Spanish campaigns see Rich 1990, op.cit. (n.30), 160, with further bibliography. Janus: Cassius Dio 53.26.5; above, n.17.
} 
justification. ${ }^{75}$ Although Aelius Gallus enjoyed little success, Petronius established a lasting settlement with the Ethiopians. It could thus be claimed that the pacification of Egypt and the neighbouring regions had been completed within the first ten-year period, and thereafter the legions stationed in Egypt seldom saw action.

Proconsuls pursued the same quest during these years. Two proconsuls of Africa, L. Sempronius Atratinus and L. Cornelius Balbus, campaigned beyond the provincial frontiers, earning what proved to be the last triumphs celebrated by commanders who were not members of the imperial family. Nothing is known of Sempronius' campaign other than the bare fact of his triumph, but about Balbus' we are better informed: he subjugated the Garamantes, a remote desert people, and Pliny preserves the names of the communities and natural features of which images were displayed in his triumph. ${ }^{76}$ Marcus Primus, proconsul of Macedonia, was less fortunate, being prosecuted for maiestas on his return. His offence, however, was not, as is usually supposed, making unauthorized war beyond the frontiers but attacking a friendly nation, the Odrysian kingdom in Thrace. ${ }^{77}$ His reason for launching the assault remains obscure.

The Parthian question, as we have seen, was the most urgent external issue facing Augustus, and, to meet public expectations, it was essential that the matter should be satisfactorily resolved within his first ten-year period. He may at first have hoped that the pretender Tiridates would succeed in ousting king Phraates, but, when Tiridates failed, Augustus prepared for a diplomatic settlement. The policy was announced in $23 \mathrm{BC}$, when Phraates' son, who had been brought to Augustus by Tiridates, was handed over to his father's envoys with the stipulation that in return he should hand back the Roman standards and prisoners. ${ }^{78}$ The main purpose of Augustus' Eastern journey of 22-19 BC was to secure Phraates' compliance, and this was achieved when Augustus reached Syria in $20 \mathrm{BC}$. Augustus had evidently decided from the outset on the policy of avoiding war with Parthia to which he adhered throughout his reign. The reason is not hard to seek. Crassus and Antony had failed disastrously in their attempts to

\footnotetext{
${ }^{75}$ Cf. Strabo 16.4.22 (780C), our only evidence for the motives of Aelius Gallus' expedition, implausibly interpreted as a flanking move against Parthia by C. Marek, 'Die Expedition des Aelius Gallus nach Arabien im Jahre 25 v. Chr.', Chiron 23 (1993), 121-156.

${ }^{76}$ Naturalis Historia 5.36-37.

${ }^{77}$ Cassius Dio 54.3.2; Rich 1990, op.cit. (n.30), 175-176.

${ }^{78}$ Cassius Dio 53.33.1-2. For Augustus' earlier dealings with Tiridates see Cassius Dio 51.18.2-3; Justin 42.5.6-9.
} 
conquer Parthia, and Augustus had no grounds for confidence that he would be more successful. If he had attempted the conquest of Parthia and failed, he would have suffered a grave loss of prestige at home, and his supremacy might even have been put at risk. It would have been folly for Augustus to hazard all he had achieved on such an enterprise if an acceptable diplomatic solution could be found. ${ }^{79}$

Also in $20 \mathrm{BC}$, an appeal from Armenia provided Augustus with a pretext for ousting the hostile king Artaxes in favour of his brother Tigranes. Augustus thus succeeded in re-establishing the Roman claim, first asserted by Pompey, to determine who should rule the Armenian kingdom. This claim was to prove the principal irritant in subsequent Roman relations with Parthia. The strategic position of Armenia between Roman Anatolia and the Parthian empire may partly account for the significance which Augustus and his successors attached to the claim, but the most important factor was probably just that Roman prestige was committed.

Thus by the time the first ten-year period expired in 18, Augustus was able to show very substantial progress in delivering the promised pacification. Roman prestige had been restored in the East; north-west Spain, which had eluded Roman control for nearly two centuries, had been brought to heel; and Roman arms had penetrated far into Africa and Arabia. Already in $22 \mathrm{BC}$ he had made a first step towards the promised restoration of his provinces to the Roman people, detaching Cyprus from Syria and handing it and Gallia Narbonensis back ${ }^{80}$ However, when the question of renewing Augustus' term was considered in 18 and again at each of the subsequent renewals, the senators will have argued that the remaining provinces were not yet secure enough to be returned to the people, and on this occasion the argument was strengthened by the fact that Gaul had so far received relatively little attention. Augustus maintained his stance that the provincial division was only temporary by accepting the renewal of his provinces for just five years, claiming that that would suffice.

The principal tasks which Augustus set himself for this five-year period, and may indeed have announced when accepting it, were carried out during his

\footnotetext{
${ }^{79}$ For judicious assessments of Augustus' Parthian policy see D. Timpe, 'Zur augusteischen Partherpolitik zwischen 30 und 20 v. Chr.', Würzburger Jahrbücher für die Altertumswissenschaft 1 (1975), 155-169; A. N. Sherwin-White, Roman Foreign Policy in the East (London, 1984), 323-341; J. B. Campbell, 'War and diplomacy: Rome and Parthia, 31 BC - AD 235', in J. W. Rich \& D. G. J. Shipley (eds.), War and Society in the Roman World (London 1993), 213-240.

${ }^{80}$ Cassius Dio 53.12.7; 54.4.1.
} 
absence in Gaul and Spain in 16-13 BC, his last extended absence from Italy: he himself re-organized the Gallic provinces, while the Alps were conquered by his legates, principally his stepsons Tiberius and Drusus. It has often been claimed that Augustus decided on the conquest of the Alps in preparation for the later advance into Germany. ${ }^{81}$ However, control of the Alps was not essential for the advance beyond the Rhine, and the conquest is better explained in its own right, as the next stage in the Augustan programme of pacification. The imposition of peace and order on this region which was so close to the heart of the empire and yet had remained for so long outside the Roman people's control was fully in accord with the objectives of that programme. The conquest of the Alps may have been part of the plans which Augustus had formed when he announced the pacification programme in $27 \mathrm{BC}$, and, if not, must certainly have been included in his plans since Terentius Varro's campaign against the Salassi in $25 \mathrm{BC}$.

So by $13 \mathrm{BC}$ it could be claimed that Augustus had brought peace to all the provinces assigned to him, and this is surely what is implied by the decreeing of the Altar of Augustan Peace on his return to Rome in that year. The gradual restoration of provinces to the Roman people was probably continued by the division of Hispania Ulterior and transfer of the southern portion as the new public province of Baetica. ${ }^{82}$ However, it would not at all have suited Augustus for his task to be thought at an end. New frontiers of pacification were needed and were supplied by the great expansion into central Europe, which began in $12 \mathrm{BC}$.

Recent disturbances provided the pretexts for the advance into central Europe. There had been recurrent fighting in the Balkans since about $18 \mathrm{BC} .83$ The Sugambri and other German tribes crossed the Rhine in $16 \mathrm{BC}$, inflicting a defeat on M. Lollius; Augustus hastened his departure from Rome, but, before he reached Gaul, Lollius had imposed a settlement. ${ }^{84} \mathrm{~A}$ further incursion in $12 \mathrm{BC}$ provided the immediate pretext for Drusus' invasion of Germany, but it must have been planned well in advance: Drusus had at his disposal a fleet and a canal

\footnotetext{
${ }^{81}$ E.g. K. Kraft, Gesammelte Aufsätze zur antiken Geschichte und Militärgeschichte I (Darmstadt 1973), 190 ff.; Wells 1972, op.cit. (n.57), 44-46; Kienast 1999, op.cit. (n.9), 359-360. Contra, K. Christ, 'Zur augusteischen Germanienpolitik', Chiron 7 (1977), 149-205, at pp. 167-189.

${ }^{82}$ Best dated c. 13 BC: Rich 1990, op.cit. (n.30), with further bibliography.

${ }^{83}$ Cassius Dio 54.20.2-3; 24.3; 28.1 .

${ }^{84}$ Cassius Dio 54.20.4-6; Velleius Paterculus 2.97.1; Tacitus, Annales 1.10.3; Suetonius, Augustus 23.1; Obsequens 71. The invasion is to be dated to $16 \mathrm{BC}$ in view of the agreement of Dio and Velleius, rather than $17 \mathrm{BC}$ with Obsequens.
} 
from the Rhine to the IJsselmeer (the fossa Drusiana), both of which would have taken a considerable time to construct, and it is likely that the redeployment to new bases on the Rhine had been in progress for some years. ${ }^{85}$ Thus the decision that a major offensive would in due course be launched in central Europe is likely to have been taken no later than $16 \mathrm{BC}$, in the aftermath of the German invasion and Lollius' defeat.

It is disputed when Augustus first formed the design of expanding in central Europe, but it seems to me most likely that his decision was prompted by the German invasion of Gaul in $16 \mathrm{BC}$ and the contemporary disturbances in the Balkans. ${ }^{86}$ The exclusion of the Balkan provinces from Augustus' original share shows that expansion in this region had not figured in his initial plans, and it was probably the renewed uprisings there that led to the change in policy. German threats to the peace of Gaul are reported on several occasions in the years before $16 \mathrm{BC}{ }^{87}$ However, the major incursion of that year gave the issue a new urgency. Dio tells us that, having taken only a fiveyear renewal of the division of the provinces in $18 \mathrm{BC}$, Augustus soon after accepted an additional five years ${ }^{88}$ If he had already decided on the advance into central Europe by $18 \mathrm{BC}$, it is hard to see why he did not take a ten-year renewal at that point. It is a tempting conjecture that Augustus took the further five-year extension in $16 \mathrm{BC}$ before his departure for Gaul and in the immediate aftermath of the German invasion, and that the new threats from Germany and in the Balkans were given as the justification.

Internal political imperatives - the need to justify the continued division of the provinces and to provide the princes of the imperial house with further opportunities to win military glory - necessitated further warfare and expansion, but central Europe was not the only possible direction. An alternative option was Britain, and it may well be that, if the Germans and the Balkan peoples had not drawn attention to themselves, it would have been there that Augustus would have turned next. He could readily have claimed, as Caesar had done before and Claudius was to do later, that the security of Gaul required the subjection of

\footnotetext{
${ }^{85}$ The 12 BC incursion: Cassius Dio 54.32.1. Preparations: Cassius Dio 54.32.2-3; Strabo 7.1.3 (290C); Tacitus, Annales 2.8.1; Suetonius, Claudius 1.2.; Wells 1972, op.cit. (n.57), 93 ff.

${ }^{86}$ For a survey of views see Christ 1977 , op.cit. (n.81), $149 \mathrm{ff}$.

${ }^{87}$ Cassius Dio 51.20.5; 51.21.6; 53.26.4; 54.11.2. It is uncertain whether Agrippa's resettlement of the Ubii on the left bank of the Rhine (Strabo 4.3.4 (194C)) took place in 39/8 BC or 20/19 BC: see J.-M. Roddaz, Marcus Agrippa (Rome, 1984), 384-388; Kienast 1999, op.cit. (n.9), 356-357.

${ }^{88}$ Cassius Dio 54.12.5.
} 
Britain to Roman rule. He had disappointed the public over Parthia, but could easily have satisfied their expectations of British conquest. ${ }^{89}$

In Illyricum the original intention may have been merely to re-establish the settlement which Augustus had achieved in his campaigns of 35-33 BC. This may explain why that region was originally allotted to Agrippa; the despatch to Germany of Tiberius and Drusus, who had the greater need to acquire military glory, suggests that Augustus regarded this as the more glamorous assignment. However, Agrippa's death led to Tiberius' transfer to Illyricum, and the Roman aims in the Balkans probably became more extensive as the fighting dragged on. In Illyricum itself Tiberius encountered repeated resistance, while L. Calpurnius Piso was summoned with reinforcements from Galatia-Pamphylia to deal with an uprising in neighbouring Thrace. By $8 \mathrm{BC}$ Roman control had been extended up to the Danube along the whole of its lower and middle course. One consequence was the demilitarization of the public provinces in this region. Illyricum was transferred to Augustus, and the legions were stationed there and in what was to become the new imperial province of Moesia, relieving the proconsuls of Macedonia of military command and leaving Africa as the only public province whose proconsul commanded a legion. .0

In Germany too the Romans' plans may have evolved in the course of the campaigns. Drusus began by advancing against the Sugambri and their allies both by sea and by land, up the Lippe valley. The defection of the Chatti obliged him to extend operations to the Main valley in $10 \mathrm{BC}$ and in $9 \mathrm{BC}$ he advanced as far as the Elbe, but died on the way back. Tiberius in $8 \mathrm{BC}$ brought the warfare to what was proclaimed as a successful conclusion, celebrated in his triumph of 1 January 7 BC. How much had been accomplished by these campaigns has been much disputed. Archaeology has shown that Roman military occupation in Germany

\footnotetext{
${ }^{89}$ On Augustan policy towards Britain see Braund 1996, op.cit. (n.42), 76 ff. Brunt 1990, op.cit. (n.1), 103-104, infers from Horatius, Carmina 4.41-52, that the British embassies to Augustus, adduced by Strabo in justification of the failure to invade (above, n.42), had already arrived by the time of the poem's composition in or soon after $15 \mathrm{BC}$. However, Horace here lists peoples against whom military or diplomatic successes had been achieved as showing awe or veneration for Augustus: te Cantaber non ante domabilis/Medusque et Indus, te profugus Scythes/ miratur .... te caede gaudentes Sygambri/compositis venerantur armis (in the case of the Sugambri the reference must be to Lollius' settlement: Cassius Dio 54.20.6). By contrast the Britons are introduced only obliquely, in association with Ocean (beluosus qui remotis/obstrepit Oceanus Britannis). This suggests that by $15 \mathrm{BC}$ no diplomatic success had yet been achieved against the Britons and that public opinion may still have envisaged the possibility of an invasion.

${ }^{90}$ Cassius Dio 53.12.4; 54.34.4; Rich 1990, op.cit. (n. 30), 141; 214.
} 
was confined for the most part to the right bank of the Rhine and its immediate hinterland, and some hold that the campaigns aimed not at conquest but merely at demonstrating Roman power. Dio's minimizing of Tiberius' achievements in 8 $\mathrm{BC}$ lends some support to this view. ${ }^{91}$ Other literary evidence, however, reveals that it is a misconception. As these sources show, all the tribes remaining in Germany up to the Elbe performed acts of surrender (deditiones); the Sugambri, the principal belligerents, were deported west of the Rhine; the Marcomanni and Suebi avoided submission by migrating eastwards, and it was surely now that Augustus ruled against pursuing the fugitives beyond the Elbe. ${ }^{92}$ This settlement satisfied traditional Roman expectations of conquest. It was indeed far from establishing full provincial government in the newly conquered region, but the same had been true of the initial phases of many earlier conquests, for example central Spain in the early second century or Caesar's Gaul. ${ }^{93}$

At the start of the year $8 \mathrm{BC}$ Augustus accepted a ten-year renewal of the division of the provinces after the usual protestations of reluctance. ${ }^{94}$ There was now no need to seek out new regions requiring pacification in order to justify the renewal. It would take a long time for the great new conquests to be absorbed and Roman control in these lands to be consolidated. This in itself provided sufficient foundation for the argument that the territories which Augustus had pacified were not yet secure enough to be handed over to the Roman people and its proconsuls. Although ten-year renewals and ritual protestations continued to the end of Augustus' reign, the division of the provinces had now effectively become permanent.

One mark of this change may be the ending of the use of the Janus ritual to mark phases of pacification. The shrine was closed for the second time, as we have seen, in $25 \mathrm{BC}$. We do not know when it was reopened: it may well have remained shut until Augustus went out to Gaul in $16 \mathrm{BC}$ immediately following

\footnotetext{
${ }^{91}$ Cassius Dio 55.6.1-4.

${ }^{92}$ Cassiodorus, Chronica Minora 2.135 (inter Albim et Rhenum Germani omnes Tiberio Neroni dediti, perhaps from Aufidius Bassus); Strabo 7.1.3-4 (290-1C); Velleius Paterculus 2.97.4; 2.108.2; Tacitus, Annales 2.26.3; 12.39.2; Suetonius, Augustus 21; Tiberius 9.2; Eutropius 7.9; Orosius 6.21.24.

${ }^{93}$ The view taken here (as already at Rich 1990, op.cit. (n.30), 223-224) is similar to that of Wolters 1999, op.cit. (n.50). Other views are surveyed by J. Deininger, 'Germaniam pacare. Zur neueren Diskussion über die Strategie des Augustus gegenüber Germanien’, Chiron 30 (2000), 749-771.

${ }^{94}$ Cassius Dio 55.6.1.
} 
the German invasion of that year. ${ }^{95}$ The third closure is equally mysterious. Dio records a senatorial decree ordaining that the shrine be closed in $11 \mathrm{BC}$, not implemented because of renewed hostilities in the Balkans. It may well be that there was no third closure and that the shrine remained open from $16 \mathrm{BC}$ until the reign of Nero. ${ }^{96}$

Augustus doubtless envisaged further military initiatives after $8 \mathrm{BC}$. Major new campaigns would be needed to enable the princes of his family to win laurels, above all his intended successors Gaius and Lucius. Possibly he was now reserving Britain for them. Fate, however, decreed otherwise. The death of Drusus and Tiberius' withdrawal to Rhodes in $6 \mathrm{BC}$ left Augustus for a time with no available commander from the imperial house. When the nineteen year old Gaius was sent east in $1 \mathrm{BC}$, the objectives were not primarily military, despite Ovid's expectations, but rather to show him off to the eastern provinces and to re-establish good relations with Parthia. In the event he did engage in some campaigning, in Arabia and, fatally, in Armenia ${ }^{97}$ However, the great wars that Augustus must have planned for the young princes were forestalled by the deaths of Lucius in $\mathrm{AD} 2$ and Gaius in $\mathrm{AD} 4$.

When Tiberius was restored to favour after Gaius' death, the initiative was resumed: rebellion in Germany was crushed with the sweeping campaigns of $\mathrm{AD}$ 4-5, and for $\mathrm{AD} 6$ an advance was planned against the Marcomanni and their ruler Maroboduus. This action, like Augustus' previous advances, was represented as necessary for the security of territories under Roman rule, in this case at least a very specious justification. ${ }^{98}$ However, the Marcomanni were

\footnotetext{
${ }^{95}$ The shrine can hardly have been opened when Augustus left for the East in $22 \mathrm{BC}$, as suggested by Syme 1984, op.cit. (n.17), 1181. Although Augustus may have used threats to ensure Parthian compliance, an announcement of war would have been inappropriate at a time when he was seeking to confirm the friendly relations initiated in $23 \mathrm{BC}$ (above, n. 78). If the shrine had been opened in 22 $\mathrm{BC}$, it would surely have been closed again after the Parthian settlement, and this closure is unlikely to have gone unrecorded.

${ }^{96}$ Cassius Dio 54.36.2; Rich 1990, op.cit. (n.30), 163; 216. Suetonius, Augustus 22, states that Augustus closed the shrine thrice, but Augustus himself merely states that the senate thrice decreed its closure (Res Gestae 13). Orosius' statement (6.22) that the shrine was closed in 2 BC (on his reckoning the year of Christ's nativity) is a patent Christianizing fiction. Syme 1984 and 1991, opp.citt. (n.17), argues for closure in $7 \mathrm{BC}$, re-opening in $1 \mathrm{BC}$.

${ }^{97}$ On Gaius Caesar in the East see F. E. Romer, 'Gaius Caesar's military diplomacy in the East', Transactions of the American Philological Association 109 (1979), 199-214; Syme 1978, op.cit. (n.54), 8-11; Syme 1995, op.cit. (n.42), 317-334.

${ }^{98}$ Velleius Paterculus 2.109 .
} 
spared: the Pannonian Revolt supervened, followed in AD 9 by Varus' disaster and the loss of all that had been gained in Germany.

It was doubtless these disappointments of his final years which led to the new policy of not extending the empire beyond its bounds which Augustus enunciated in his posthumous advice. Its significance, however, remains ambivalent. In Germany, in particular, it is not clear where Augustus wished the bounds of empire to be set. The Rhine was the effective limit of Roman control at the time of his death, but the presence of a substantial army on the Rhine under the command of Germanicus suggests that he had not abandoned the hope of reestablishing Roman control up to the Elbe. That certainly was Germanicus' plan, and it was left to Tiberius in $\mathrm{AD} 16$ to order the final withdrawal to the Rhine. ${ }^{99}$

It is likely enough that until his last years Augustus envisaged that Roman expansion would continue and that over time Roman claims to world rule would come increasingly to correspond to the realities. However, he did not envisage universal conquest by force of arms, for towards Parthia it was his settled principle that the Romans should proceed by diplomacy rather than by military might. Augustus' external policies were in any case not shaped by a global strategic conception. They evolved over time, and were determined above all by internal political imperatives and by his personal ambitions for himself and his successors, with a central part being played, particularly in the first half of his sole reign, by the programme of pacification which he presented as the justification for the division of the provinces by which he perpetuated his power. ${ }^{100}$

Nottingham, March 2003

\footnotetext{
${ }^{99}$ For the view that Augustus still regarded the Elbe as the boundary see e.g. Kienast (1999), op.cit. (n.9), 373-375.

${ }^{100}$ Earlier versions of this paper were given at the Rome conference which gave rise to this volume and also at Aberystwyth, Leeds, Manchester, Newcastle, Paris and Perugia. I am very grateful to the audiences on these occasions for their comments.
} 